\title{
Identification and Evaluation of 21 Novel Microsatellite Markers from the Autumnal Moth (Epirrita autumnata) (Lepidoptera: Geometridae)
}

\section{Siv Grethe Aarnes ${ }^{1, *}$, Ida Fløystad ${ }^{1}$, Julia Schregel ${ }^{1}$, Ole Petter Laksforsmo Vindstad ${ }^{2}$, Jane Uhd Jepsen ${ }^{3}$, Hans Geir Eiken ${ }^{1}$, Rolf A. Ims ${ }^{2}$ and Snorre B. Hagen ${ }^{1, *}$}

1 Norwegian Institute for Bioeconomy Research (NIBIO), Norwegian Institute for Bioeconomy Research, Svanhovd, 9925 Svanvik, Norway; E-Mails: Ida.floystad@nibio.no (I.F.); julia.schregel@nibio.no (J.S.); hansgeir.eiken@nibio.no (H.G.E.)

2 Department of Arctic and Marine Biology, University of Tromsø, 9294 Tromsø, Norway; E-Mails: ole.p.vindstad@uit.no (O.P.L.V.); rolf.ims@uit.no (R.A.I.)

3 Norwegian Institute for Nature Research (NINA), 9296 Tromsø, Norway; E-Mail: Jane.Jepsen@nina.no

* Authors to whom correspondence should be addressed; E-Mails: siv.grethe.aarnes@nibio.no (S.G.A.); snorre.hagen@nibio.no (S.B.H.); Tel.: +47-93-24-01-97 (S.B.H.); Fax: +47-61-14-74-07 (S.B.H.).

Academic Editor: Lee A. Bulla

Received: 20 August 2015 / Accepted: 11 September 2015 / Published: 17 September 2015

\begin{abstract}
The autumnal moth (Epirrita autumnata) is a cyclically outbreaking forest Lepidoptera with circumpolar distribution and substantial impact on Northern ecosystems. We have isolated 21 microsatellites from the species to facilitate population genetic studies of population cycles, outbreaks, and crashes. First, PCR primers and PCR conditions were developed to amplify 19 trinucleotide loci and two tetranucleotide loci in six multiplex PCR approaches and then analyzed for species specificity, sensitivity and precision. Twelve of the loci showed simple tandem repeat array structures while nine loci showed imperfect repeat structures, and repeat numbers varied in our material between six and 15 . The application in population genetics for all the 21 microsatellites were further validated in 48 autumnal moths sampled from Northern Norway, and allelic variation was detected in 19 loci. The detected numbers of alleles per locus ranged from two to 13, and the observed and expected heterozygosities varied from 0.04 to 0.69 and 0.04 to 0.79 , respectively. Evidence for linkage disequilibrium was found for six loci as well as indication of one
\end{abstract}


null allele. We find that these novel microsatellites and their multiplex-PCR assays are suitable for further research on fine- and large-scale population-genetic studies of Epirrita autumnata.

Keywords: tri- and tetranucleotide microsatellites; multiplex PCR; Lepidoptera; population genetics

\section{Introduction}

The autumnal moth (Epirrita autumnata) is a forest pest insect with cyclic outbreak dynamics, widespread across the northern hemisphere. In the northern-boreal birch forests of Fennoscandia, outbreaks by autumnal moth and other defoliating geometrid moths, in particular winter moth (Operopthera brumata) but locally also the ecologically similar and recently established scarce umber moth (Agriopis aurantiaria), may have severe and large-scale impacts on both tree and understory layers [1-4]. This includes local or regional defoliation of mountain birch (Betula pubescens ssp. tortuosa) and sometimes forest death following multiyear defoliation [5]. The impact of the outbreaks may cascade through other food web compartments [4] and, occasionally, extend into neighboring tundra ecosystems [6]. These geometrid moth species are a model system in population ecology, which is partly due to the pronounced spatial population synchrony and decadal population cycles [7-9], but also due to the rapid outbreak range shifts shown by these three species during recent decades due to climate warming [10-12]. However, so far, no microsatellites have been isolated and characterized from any of these species.

Development of microsatellite DNA markers for identification and application of lepidopteran species is difficult, associated to high similarity in flanking regions between different microsatellites within the same species [13-15] and/or the lack of conserved flanking regions leading to unrepeatable banding patterns [16]. In addition, the sequences flanking the microsatellites have been shown to have a high incidence of single nucleotide polymorphisms and indels [17]. These properties can result in a deficit of heterozygotes due to the presence of null alleles [14]. Nevertheless, microsatellites can be used for lepidopterans with proper attention being paid to these issues [17-20]. The application of next generation sequencing of enriched genomic libraries has previously been shown to be favorable for development of short tandem repeats (STR) in Lepidoptera, as suggested in [18] and shown in several other studies $[19,21,22]$.

Thus, we have here applied Sanger sequencing of enriched genomic libraries to identify novel Epirrita autumnata (E. autumnata) microsatellites. Furthermore, we have developed multiplex-PCR assays for 21 of those loci. We have also performed tests for species specificity, measurements of sensitivity and precision for all the 21 microsatellites, and evaluated these assays in a Northern European E. autumnata population. With the species specificity test we tested for cross-amplification with the two sympatric outbreak species winter moth and scarce umber moth, as a common set of microsatellites for all three species would greatly facilitate comparative population genetic studies of population cycles, outbreaks, crashes and climate driven range shifts. 


\section{Results and Discussion}

Genomic screening of 192 contigs from E. autumnata yielded in total 90 sequences that contained an STR, and 40 STRs were selected for the development of primer sets after elimination of the dinucleotide motifs and deletion of regions where the microsatellite was too close to an end of the sequence. The 40 primer sets were tested using DNA from four moth samples to insure amplification of an appropriate amplicon. Of these, 27 were selected for detailed genotype analysis and tested on 12 field collected larvae samples as well as on 15 cultivated larvae samples. Among these 27 microsatellites, 21 showed unambiguous genotype patterns, and gave successful amplification.

The 21 microsatellites were then successfully organized into six PCR multiplex panels, making genotyping faster and cost effective, which is important if a large number of samples have to be analyzed for population genetic studies. The multiplex panels had also easily readable chromatograms with very low stutter peaks. Figure 1 shows the results obtained using these six multiplex PCRs, while primers and combination of markers used in each multiplex reaction are given in Table 1.

Amplifications for Operophtera brumata and Agriopis aurantiaria were unsuccessful, indicating species specificity of the developed primers to E. autumnata, and thus showing their applicability to comparative population genetic studies of these sympatric outbreak species. Development of species-specific primers for the two other species is necessary.

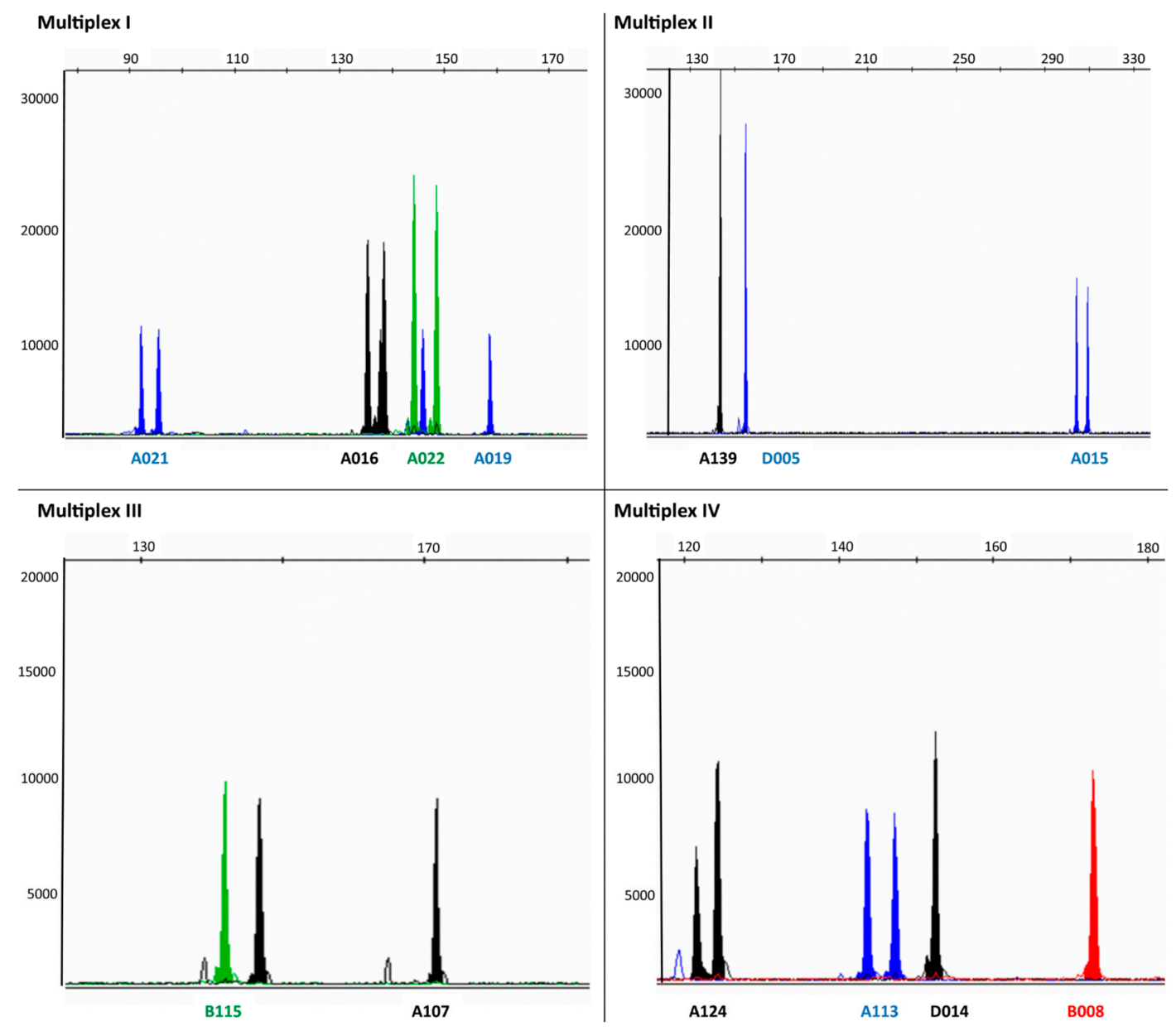

Figure 1. Cont. 

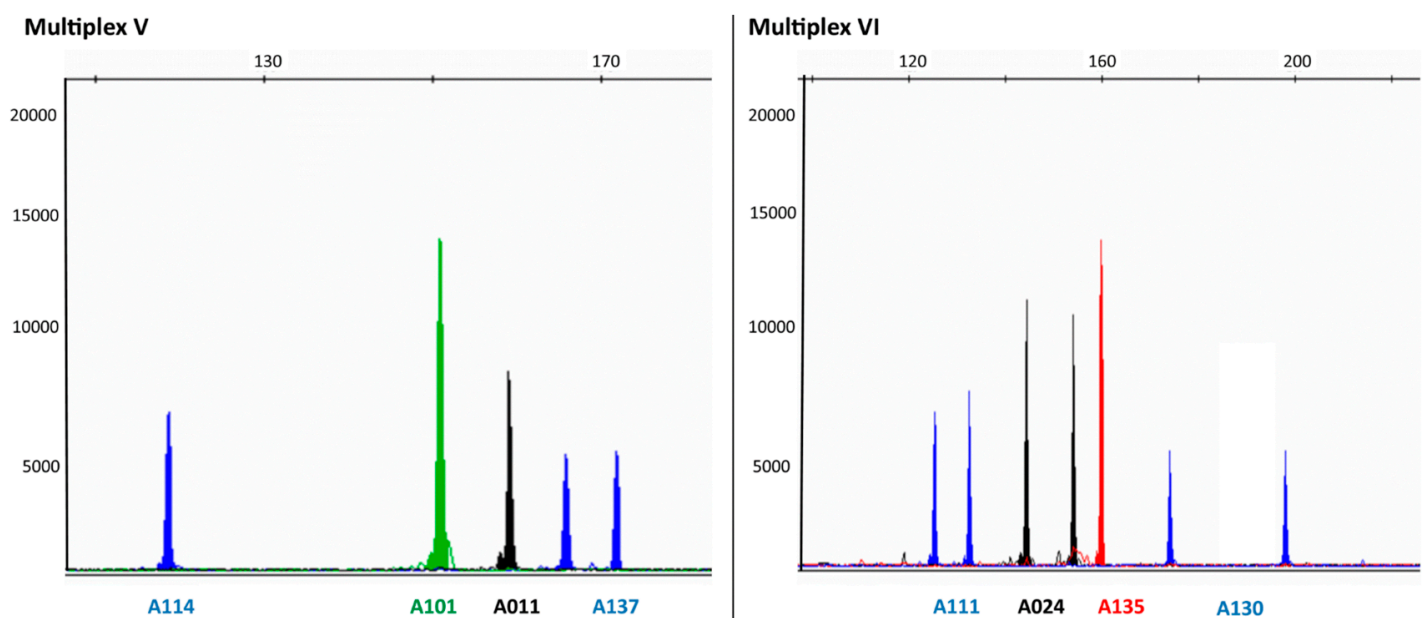

Figure 1. Chromatograms from capillary electrophoresis (ABI 3130xl) showing multiplex PCR reactions I-VI (see also Table 1) for the 21 microsatellites developed for E. autumnata. The peak height (Relative fluorescence units (RFU)) is indicated on the $Y$-axis, and fragment length (base-pairs) is indicated on the $X$-axis. The names of the microsatellites markers are indicated below the peaks.

Table 1. Twenty-one microsatellite loci arranged into six multiplex PCR panels for E. autumnata.

\begin{tabular}{|c|c|c|c|c|c|c|}
\hline $\begin{array}{c}\text { Multiplex } \\
\text { Panel }\end{array}$ & Locus & Primer Sequences $\left(5^{\prime}-3^{\prime}\right)^{a}$ & $\begin{array}{c}\text { Repeat } \\
\text { Motif }\end{array}$ & $\begin{array}{c}\text { Size } \\
\text { Range } \\
(\text { bp) } \\
\end{array}$ & $\begin{array}{c}\text { Primer } \\
\text { Conc., } \\
\text { Dye }\end{array}$ & $\begin{array}{c}\text { GenBank } \\
\text { Accession } \\
\text { Number }\end{array}$ \\
\hline \multirow[t]{9}{*}{ I } & A021 & F: CCTAAGAGGGAGGCCCATGT & TGA & $86-95$ & $2 \mu \mathrm{M}, \mathrm{FAM}$ & KT428619 \\
\hline & & R: CAGCTTGGTTCGTTAGCAAGG & & & & \\
\hline & A019 & F: GCGTTGGCGCATCTGTAAAT & CAT & $146-173$ & $3 \mu \mathrm{M}, \mathrm{FAM}$ & KT428620 \\
\hline & & R: CGCCACAGAGGTCGTCAAA & & & & \\
\hline & A022 & F: CTGCGTGCTAAAACCTACGGA & CAT & $141-147$ & $1 \mu \mathrm{M}, \mathrm{VIC}$ & KT428621 \\
\hline & & R: CAGCAGTGGACTTCTTCTGGC & & & & \\
\hline & 1016 & F: AGACCTACACCTGA & $C \Delta T$ & $125 \quad 144$ & 3 MM NED & КТАว \\
\hline & A010 & GTGCATCTTAGTT & CAI & $15 J-141$ & о $\mu \mathrm{M}, \mathrm{NED}$ & N1420022 \\
\hline & & R: CCATCCCAGGTGTGGTGATT & & & & \\
\hline \multirow[t]{7}{*}{ II } & D005 & F: CGGTGGTTGCTATGGGTGTT & CTT & $142-163$ & $2 \mu \mathrm{M}, \mathrm{FAM}$ & KT428623 \\
\hline & & R: TTGCATTCTATGTGGGAGGCT & & & & \\
\hline & A015 & F: AATTGTATGCCACCGCTGCT & CAT & $301-325$ & $2 \mu \mathrm{M}, \mathrm{FAM}$ & KT428624 \\
\hline & & R: TCCGTCTGCCAAGTGTA & & & & \\
\hline & A139 & F: ACCTGCGATTACCAATCCGA & GAT & $140-149$ & $1 \mu \mathrm{M}, \mathrm{NED}$ & KT428625 \\
\hline & & R: TTCCGTGGTTCTTCT & & & & \\
\hline & & TCATCAAC & & & & \\
\hline \multirow{4}{*}{ III } & P115 & F: TTATAGGTGTCGGT & $\triangle C T$ & 141148 & $24 \mathrm{M}$ VIC & КТАР2626 \\
\hline & DIIS & TAAACACTTTAAAAAC & $A C 1$ & $141-140$ & $2 \mu \mathrm{N}, \mathrm{vic}$ & 11420020 \\
\hline & & R: GGTTAAGGCTGCGC & & & & \\
\hline & & TAAAGCT & & & & \\
\hline
\end{tabular}


Table 1. Cont.

\begin{tabular}{|c|c|c|c|c|c|c|}
\hline $\begin{array}{c}\text { Multiplex } \\
\text { Panel }\end{array}$ & Locus & Primer Sequences $\left(5^{\prime}-3^{\prime}\right)^{a}$ & $\begin{array}{c}\text { Repeat } \\
\text { Motif }\end{array}$ & $\begin{array}{c}\text { Size } \\
\text { Range } \\
(\text { bp })^{b} \\
\end{array}$ & $\begin{array}{l}\text { Primer } \\
\text { Conc., } \\
\text { Dye }\end{array}$ & $\begin{array}{c}\text { GenBank } \\
\text { Accession } \\
\text { Number }\end{array}$ \\
\hline III & A107 & $\begin{array}{c}\text { F: TAGGGCCAGCAGTGGACTTC } \\
\text { R: GTTTCTTTGGATG } \\
\text { TCCCTTGGCCTTTA }\end{array}$ & ATG & $147-201$ & $2 \mu \mathrm{M}, \mathrm{NED}$ & KT428627 \\
\hline \multirow[t]{4}{*}{ IV } & A124 & $\begin{array}{l}\text { F: TGAATCGGTGCTCCAATAGGA } \\
\text { R: GTCTCTGTTGACCCCAGGGA }\end{array}$ & TAA & $115-124$ & $3 \mu \mathrm{M}, \mathrm{NED}$ & KT428628 \\
\hline & A113 & $\begin{array}{c}\text { F: AGACCTCGTCCAACAGTGGG } \\
\text { R: AACATTGGACGAT } \\
\text { CTTATCGCC }\end{array}$ & GAT & $144-165$ & $1 \mu \mathrm{M}, \mathrm{FAM}$ & KT428629 \\
\hline & D014 & $\begin{array}{c}\text { F: TCGTTTTCATCTATT } \\
\text { ATTAGTTTAGGATTCA } \\
\text { R: TTGTTGCACGCCTTAAATGG }\end{array}$ & CAAT & $140-156$ & $2 \mu \mathrm{M}, \mathrm{NED}$ & KT428630 \\
\hline & B008 & $\begin{array}{l}\text { F: TGCATTGTAATAGG } \\
\text { ACCTTCATATTTTT } \\
\text { R: TTATAGGATCACTT } \\
\text { TGTTGTCCGTCT }\end{array}$ & ACAG & $173-178$ & $5 \mu \mathrm{M}, \mathrm{PET}$ & KT428631 \\
\hline \multirow[t]{4}{*}{ V } & A114 & $\begin{array}{c}\text { F: TGTCGAGCTCTA } \\
\text { CAAAAACTGCA } \\
\text { R: AATTGGGCCTCAGGTTTCTGT }\end{array}$ & CAT & 118 & $2 \mu \mathrm{M}, \mathrm{FAM}$ & KT428632 \\
\hline & A101 & $\begin{array}{c}\text { F: GAAGCCGCGCTGTTTCTTAA } \\
\text { R: GAGAGGTCGTCG } \\
\text { AAACACCCT } \\
\end{array}$ & GTT & 151 & $1 \mu \mathrm{M}, \mathrm{VIC}$ & KT428633 \\
\hline & A011 & $\begin{array}{l}\text { F: CTAGACCGGAGGCAAACCAA } \\
\text { R: CAAAATGACGGTTTGAGCGA }\end{array}$ & TGA & $153-159$ & $0.5 \mu \mathrm{M}, \mathrm{NED}$ & KT428634 \\
\hline & A137 & $\begin{array}{l}\text { F: GATCCAGGATCTGAAGCGGA } \\
\text { R: AAGACCGTTCGTCATGGCAT }\end{array}$ & CAT & $153-174$ & $1 \mu \mathrm{M}$, FAM & KT428635 \\
\hline \multirow[t]{4}{*}{ VI } & A111 & $\begin{array}{c}\text { F: GGCGGAGGTCTTTTCTAGCAG } \\
\text { R: AACAAGTTTGG } \\
\text { GTTGCAAAAGTTT } \\
\end{array}$ & ATG & $122-137$ & $2 \mu \mathrm{M}, \mathrm{FAM}$ & KT428636 \\
\hline & A130 & $\begin{array}{l}\text { F: AACACACTCGAGGGTCCCAA } \\
\text { R: GTTCTAGGGCCAGCAGTGGA }\end{array}$ & CAT & $173-227$ & $3 \mu \mathrm{M}, \mathrm{FAM}$ & KT428637 \\
\hline & A135 & $\begin{array}{l}\text { F: TCCTCCAACTCTTTCCGTGG } \\
\text { R: TTATGGGTGAGGCTTCGTCC }\end{array}$ & CAT & $160-187$ & $1 \mu \mathrm{M}, \mathrm{PET}$ & KT428638 \\
\hline & A024 & $\begin{array}{c}\text { F: TCGTCTGTAGAT } \\
\text { ATCAACTGCTGGA } \\
\text { R: GTGGACGTAAGCAGGCTGGT }\end{array}$ & CAT & 145-199 & $1 \mu \mathrm{M}, \mathrm{NED}$ & KT428639 \\
\hline
\end{tabular}

${ }^{\mathrm{a}} \mathrm{F}$ forward, $\mathrm{R}$ reverse; ${ }^{\mathrm{b}}$ Allele size range in base pairs observed in 48 individuals of E. autumnata (see Table 4); and Conc., Concentration.

We tested a concentration series of $20,10,1,0.5,0.2,0.1,0.05,0.04,0.03,0.02$ and $0.01 \mathrm{ng}$ of template DNA in the six multiplex reactions. All markers successfully typed with signals above the lower peak height threshold of $200 \mathrm{RFU}$ with template DNA in the range 20-1.0 ng. The sample material in this work had high DNA-concentration, using fresh larval head material for extraction, and the 
protocol were optimized to extract approximately $20 \mathrm{ng}$ of DNA. This indicates a relatively low sensitivity of the assays, and for studies with other material with degraded DNA, like decades-old dried museum specimens, a new optimization is likely needed. The extraction protocol presented here should be ideal for most population genetic applications where field collected larvae or adults are used as source material.

We also tested the within-run precision using ten independent amplifications and subsequent runs of one tissue-sample of E. autumnata (Table 2). These results show that the standard deviations (S.D.) from allele length measurements of all the 21 loci tested were between 0.03 and $0.1 \mathrm{bp}$. The electrophoretic separation is, thus, not affected by origin of the template (Table 2).

DNA sequencing was performed on the largest and the smallest alleles in each marker found so far in the material. The sequencing revealed that all size variation observed between the two alleles selected from the same loci could be explained by variation in repeat numbers in the tandem repeat arrays (Table 3). Nineteen loci were tandem arrays of trinucleotide repeats while two had a repeat array of tetranucletide repeats (D014 and B008). Twelve of the loci showed simple tandem repeat array structures while nine loci showed complex repeat structures, often common in microsatellites in insects [23].

Table 2. Measurements of precision for 21 STRs from E. autumnata.

\begin{tabular}{cccc}
\hline Locus & Allele/Genotype $^{\mathbf{a}}$ & Mean $^{\mathbf{b}}$ & S.D. (bp) $^{\mathbf{c}}$ \\
\hline A021 allele A & 92 & 92.24 & 0.07 \\
A021 allele B & 95 & 95.49 & 0.1 \\
A019 allele A & 135 & 135.36 & 0.08 \\
A019 allele B & 138 & 138.47 & 0.08 \\
A022 allele A & 145 & 145.92 & 0.08 \\
A022 allele B & 188 & 188.56 & 0.1 \\
A016 allele A & 144 & 144.20 & 0.1 \\
A016 allele B & 147 & 148.62 & 0.09 \\
D005 allele A & 148 & 148.43 & 0.07 \\
D005 allele B & 154 & 154.99 & 0.03 \\
A015 allele A & 301 & 301.08 & 0.07 \\
A015 allele B & 310 & 309.28 & 0.07 \\
A139 allele A & 143 & 143.53 & 0.07 \\
B115 allele A & 141 & 141.70 & 0.06 \\
A107 allele A & 147 & 146.45 & 0.09 \\
A107 allele B & 201 & 201.98 & 0.05 \\
A124 allele A & 121 & 121.44 & 0.06 \\
A124 allele B & 124 & 124.24 & 0.07 \\
A113 allele A & 147 & 147.06 & 0.08 \\
D014 allele A & 152 & 152.47 & 0.07 \\
B008 allele A & 181 & 181.21 & 0.06 \\
A114 allele A & 118 & 118.48 & 0.06 \\
A101 allele A & 151 & 150.68 & 0.07 \\
A011 allele A & 159 & 158.89 & 0.08 \\
\hline
\end{tabular}


Table 2. Cont.

\begin{tabular}{cccc}
\hline Locus & Allele/Genotype $^{\mathbf{a}}$ & Mean $^{\mathbf{b}}$ & S.D. (bp) $^{\mathbf{c}}$ \\
\hline A137 allele A & 165 & 165.68 & 0.09 \\
A137 allele B & 171 & 171.55 & 0.08 \\
A111 allele A & 125 & 125.36 & 0.07 \\
A111 allele B & 131 & 131.64 & 0.07 \\
A130 allele A & 173 & 174.16 & 0.07 \\
A130 allele B & 227 & 227.31 & 0.08 \\
A135 allele A & 160 & 159.92 & 0.08 \\
A024 allele A & 154 & 154.10 & 0.06 \\
A024 allele B & 172 & 172.09 & 0.09 \\
\hline
\end{tabular}

${ }^{\mathrm{a}}$ Genotype nomenclature is based on PCR fragment sizes.; ${ }^{\mathrm{b}}$ Mean value allele sizes when measured with POP7 on $\mathrm{ABI} 3730$; and ${ }^{\mathrm{c}} \mathrm{SD}$ from within-run measurement of 10 run per sample.

Table 3. DNA sequencing of tandem repeat structure of 21 microsatellites from E. autumnata.

\begin{tabular}{|c|c|c|c|}
\hline Locus & Allele/Genotype ${ }^{\text {a }}$ & Number Repeats & Repeat Structure \\
\hline A021 allele A & 92 & $6 \mathrm{R}$ & $(\mathrm{TGA})_{6}$ \\
\hline A021 allele B & 95 & $7 \mathrm{R}$ & $(\mathrm{TGA})_{7}$ \\
\hline A019 allele A & 146 & - & $(\mathrm{CAT})_{n}(\mathrm{AAT})(\mathrm{CAT})_{n} *$ \\
\hline A022 allele A & $141 *$ & $5 \mathrm{R}$ & $(\mathrm{CAT})_{5}$ \\
\hline A022 allele B & $147 *$ & $6 \mathrm{R}$ & $(\mathrm{CAT})_{6}$ \\
\hline A016 allele $\mathrm{A}$ & 138 & $6 \mathrm{R}$ & $(\mathrm{CAT})_{6}$ \\
\hline D005 allele A & 148 & $7 \mathrm{R}$ & $(\mathrm{CTT})_{7}$ \\
\hline D005 allele B & 154 & $9 \mathrm{R}$ & $(\mathrm{CTT})_{9}$ \\
\hline A015 allele A & 301 & $5 \mathrm{R}$ & $(\mathrm{CAT})_{5}$ \\
\hline A015 allele B & 322 & $6 \mathrm{R}$ & $(\mathrm{CAT})_{6}$ \\
\hline A139 allele A & 140 & $7 \mathrm{R}$ & $(\mathrm{GAT})_{7}$ \\
\hline A139 allele B & 143 & $8 \mathrm{R}$ & $(\mathrm{GAT})_{8}$ \\
\hline B115 allele A & 141 & $7 \mathrm{R}$ & $(\mathrm{ACT})_{1}(\mathrm{TT})(\mathrm{ACT})_{1}(\mathrm{ACA})(\mathrm{ACT})_{5}$ \\
\hline B115 allele B & 144 & $8 \mathrm{R}$ & $(\mathrm{ACT})_{1}(\mathrm{TT})(\mathrm{ACT})_{1}(\mathrm{ACA})(\mathrm{ACT})_{6}$ \\
\hline A107 allele A & 147 & - & - \\
\hline A107 allele B & 201 & $14 \mathrm{R}$ & $\begin{array}{c}(\mathrm{ATG})_{6}(\mathrm{AGGCTG})(\mathrm{ATG})_{3}(\mathrm{ACG})(\mathrm{ATG})_{3} \\
(\mathrm{CTG})(\mathrm{ATG})_{2}\end{array}$ \\
\hline A124 allele A & 121 & $7 \mathrm{R}$ & $(\mathrm{TAA})_{7}$ \\
\hline A124 allele B & 124 & $8 \mathrm{R}$ & $(\mathrm{TAA})_{8}$ \\
\hline A113 allele A & 147 & $9 \mathrm{R}$ & $(\mathrm{GAT})_{9}$ \\
\hline A113 allele B & 165 & $15 \mathrm{R}$ & $(\mathrm{GAT})_{15}$ \\
\hline D014 allele A & 140 & - & $(\mathrm{CAAT})_{n}(\mathrm{CAAC})(\mathrm{CAT})_{n} *$ \\
\hline D014 allele B & 142 & - & - \\
\hline B008 allele A & 173 & $5 \mathrm{R}$ & $(\mathrm{ACAG})_{2}(\mathrm{ACAT})(\mathrm{ACAG})_{3}$ \\
\hline B008 allele B & 181 & - & - \\
\hline A114 allele A & 118 & $6 \mathrm{R}$ & $(\mathrm{CAT})_{6}$ \\
\hline A101 allele A & 151 & $8 \mathrm{R}$ & $(\mathrm{GTT})_{3}(\mathrm{GT})(\mathrm{GTT})_{2}(\mathrm{~T})(\mathrm{GTT})_{1}(\mathrm{GTA})(\mathrm{GTT})_{2}$ \\
\hline A011 allele $\mathrm{A}$ & 159 & $6 \mathrm{R}$ & $(\mathrm{TGA})_{3}(\mathrm{TGT})(\mathrm{TGA})_{3}$ \\
\hline
\end{tabular}


Table 3. Cont.

\begin{tabular}{cccc}
\hline Locus & Allele/Genotype $^{\text {a }}$ & Number Repeats & Repeat Structure $^{\text {A137 allele A }}$ \\
\hline A137 allele B & 165 & $7 \mathrm{R}$ & $(\mathrm{CAT})_{7}$ \\
A111 allele A & 125 & $9 \mathrm{R}$ & $(\mathrm{CAT})_{9}$ \\
A111 allele B & 134 & $10 \mathrm{R}$ & $(\mathrm{ATG})_{10}$ \\
A130 allele A & 173 & $7 \mathrm{R}$ & $(\mathrm{ATG})_{7}$ \\
& & $6 \mathrm{R}$ & $(\mathrm{CAT})_{6}$ \\
A130 allele B & 227 & $19 \mathrm{R}$ & $(\mathrm{CAT})_{7}(\mathrm{CAGCCT})(\mathrm{CAT})_{6}(\mathrm{CAGCCTCAC})$ \\
A135 allele A & 160 & $10 \mathrm{R}$ & $(\mathrm{CAT})_{6}$ \\
A024 allele A & 145 & $6 \mathrm{R}$ & $(\mathrm{CAT})_{10}$ \\
A024 allele B & 187 & $17 \mathrm{R}$ & $(\mathrm{CAT})_{6}$ \\
\hline
\end{tabular}

- Sequencing not interpretable; * Structure repeat is taken from the DNA sequences done at Armalil; and

${ }^{a}$ Nomenclature of alleles is based on PCR fragment size.

Allele size distribution was consistent for all STRs, except for A111, A130, B115 and D014. The irregular allele sizes observed in these STR markers are possibly caused by single base indels changing the expected sizes (see Table 3). This is also shown in other studies [17,24], and should be verified by sequencing the relevant alleles.

The six final multiplex PCR panels were applied to DNA samples from 48 E. autumnata from Northern Norway, and we found 98 alleles (Table 4) for all the 21 microsatellite loci, and allelic variation was detected in 19 of those, ranging from 2 to 13 (Table 4). Observed and expected heterozygosities ranged from 0.04 to 0.69 and 0.04 to 0.79 , respectively.

Table 4. Basic statistics of 21 microsatellites loci developed for E. autumnata in a survey of 48 individuals from Northern Norway.

\begin{tabular}{cccccccc}
\hline Locus & $\mathbf{N}_{\mathbf{A}}$ & $\mathbf{H}_{\mathbf{O}}$ & $\mathbf{F}_{\mathbf{I S}}$ & $\mathbf{H}_{\mathbf{E}}$ & $\mathbf{P I}$ & $\mathbf{F}_{\text {NULL }}$ & HWE $\boldsymbol{p}$ Values ${ }^{\text {a }}$ \\
\hline $\mathrm{A} 021$ & 3 & 0.438 & 0.1258 & 0.495 & 0.32 & 0.0249 & 0.2676 \\
$\mathrm{~A} 019$ & 3 & 0.553 & -0.1423 & 0.479 & 0.32 & -0.0496 & 0.9699 \\
$\mathrm{~A} 022$ & 3 & 0.4375 & 0.2654 & 0.5877 & 0.24 & 0.0918 & $0.0054^{* *}$ \\
$\mathrm{~A} 016$ & 3 & 0.1667 & -0.0697 & 0.1543 & 0.72 & -0.0111 & 1.0000 \\
D005 & 7 & 0.6042 & 0.0347 & 0.6191 & 0.19 & 0.0091 & 0.6835 \\
A015 & 5 & 0.4583 & 0.3233 & 0.6680 & 0.17 & 0.1322 & $0.0001^{* *}$ \\
A139 & 3 & 0.229 & 0.1009 & 0.252 & 0.59 & 0.0178 & 0.2429 \\
B115 & 5 & 0.354 & 0.2766 & 0.483 & 0.34 & 0.0913 & $0.0420^{*}$ \\
A107 & 8 & 0.596 & 0.1796 & 0.717 & 0.12 & 0.0571 & $0.0341^{*}$ \\
A124 & 4 & 0.479 & -0.0810 & 0.439 & 0.39 & -0.0225 & 0.7396 \\
A113 & 7 & 0.158 & 0.7739 & 0.682 & 0.14 & 0.3127 & $0.0000^{* *}$ \\
D014 & 6 & 0.106 & 0.4148 & 0.179 & 0.68 & 0.0625 & $0.0026 *$ \\
B008 & 2 & 0.08 & 0.6336 & 0.211 & 0.64 & 0.1083 & $0.0194 *$ \\
A114 & 1 & 0 & 0 & 0 & 1.00 & 0 & No \\
A101 & 1 & 0 & 0 & 0 & 1.00 & 0 & No \\
A011 & 2 & 0.041 & -0.0108 & 0.041 & 0.92 & -0.0009 & 1.0000 \\
A137 & 5 & 0.688 & 0.0061 & 0.645 & 0.16 & 0.0034 & 0.5214 \\
\hline
\end{tabular}


Table 4. Cont.

\begin{tabular}{cccccccc}
\hline Locus & $\mathbf{N}_{\mathbf{A}}$ & $\mathbf{H}_{\mathbf{O}}$ & $\mathbf{F}_{\text {IS }}$ & $\mathbf{H}_{\mathbf{E}}$ & PI & F $_{\text {NULL }}$ & HWE $\boldsymbol{p}$ Values \\
\hline A111 & 8 & 0.404 & 0.4519 & 0.726 & 0.12 & 0.1722 & $0.0000 * *$ \\
A130 & 7 & 0.568 & 0.1975 & 0.698 & 0.14 & 0.055 & 0.0603 \\
A135 & 2 & 0.255 & -0.1231 & 0.225 & 0.62 & -0.0246 & 1.0000 \\
A024 & 13 & 0.614 & 0.2379 & 0.794 & 0.06 & 0.0833 & $0.0014 *$ \\
\hline
\end{tabular}

$\mathrm{N}_{\mathrm{A}}$ : number of different alleles; $\mathrm{H}_{\mathrm{O}}$ : observed heterozygosity; $\mathrm{F}_{\mathrm{IS}}$ : inbreeding value; $\mathrm{H}_{\mathrm{E}}$ : expected heterozygosity; PI: probability of identity; $\mathrm{F}_{\mathrm{NULL}}$ : Null-alleles estimated with the Brookfiled1 method implemented in Micro-Checker (van Oosterhout et al., 2006 [25]); HWE: significance of departure from Hardy-Weinberg equilibrium; $*<0.05, * *<0.01$; and ${ }^{\text {a }}$ Based on assay of 48 individuals from each locus.

For this survey, we observed a significant linkage disequilibrium $(p<0.05)$ for nine of the 210 pairwise comparisons between loci after sequential Bonferroni correction, particularly involving loci A015, A024, A111, A130, B115 and D014 (see Table S1).

Of the nine loci that deviated significantly from HWE, three loci (A111, A113 and B008) showed large heterozygote deficiencies. These three loci also exhibited overall significant excess of homozygotes with null allele frequency of $0.172,0.313$ and 0.108 , respectively, possibly indicating the presence of null allele in this population. Simulations have shown that the bias induced by null alleles is negligible at frequencies below 0.2 [26], and therefore in this population only A113 showed null allele frequency that is not negligible. Excess of homozygotes can also be due to small sample size of 48 individuals, but heterozygote deficiencies and the presence of null allele are highly common in Lepidoptera $[20,27,28]$. Future population studies applying these loci in a broader sampling area will help clarify both this question and whether any of the observed deviations from linkage and HW also occur consistently in other populations, which may suggest that the respective loci should be excluded from the marker set.

\section{Materials and Methods}

\subsection{Sampling and Materials}

For method development, PCR specificity and precision larval samples from a laboratory culture of E. autumnata, Operophtera brumata and Agriopis aurantiaria were used. The cultivated larvae originated from eggs laid by multiple females collected at Reinøya near Tromsø in Northern Norway. Thus, the cultivated larvae originated from different families within the same population. For the sensitivity test and the tests of the final set of 21 microsatellite markers (see below) we used 48 individual E. autumnata larvae collected at Storelva near Tromsø in Northern Norway. The 48 larvae were collected from birch trees along a linear transect with 12 individual sampling stations spaced at $200 \mathrm{~m}$ intervals. This was done to ensure that the larval samples were collected from a reasonably large area within the study site. Four larvae were collected from each station. Each larvae was stored individually in an Eppendorf tube and frozen at $-18{ }^{\circ} \mathrm{C}$ until it was used in the DNA analysis. 


\subsection{Identification of Microsatellites Markers}

A total of 40 adult moth samples of E. autumnata were selected and sent to Armalil Microsatellite Identification Service (www.geneticidentificationservices.com) for genome sequencing and construction of enriched genomic libraries. Here, four libraries, employing 16 capture motifs (6 TETRAs, 8 TRIs and 2 DIs), were produced using magnetic bead capture technology, and a total of 192 clones from these libraries were sequenced by Sanger sequencing using an ABI 3100 Genetic Analyzer (Applied Biosystems (ABI), Waltham, MA, USA) with a Big Dye Terminator V3.1 Cycle Sequencing Kit (ABI). Among these sequences, there were 90 microsatellite loci, and from these regions, with help of ABI Primer Express primer determining program, 40 were selected for the development of primer sets after elimination of the di-nucleotide motifs and deletion of regions where the microsatellite was too close to an end of the sequence. The 40 primer sets were tested using DNA from four moth samples to insure amplification of an appropriate amplicon. Of those tested, 27 were selected for detailed genotype analysis and tested on 16 moth samples using ABI3700 genetic analyzer.

\subsection{DNA Extraction}

DNA was extracted from head tissue of E. autumnata using Qiagen DNeasy Tissue kit (Qiagen, Hilden, Germany) following the manufactures' instructions, except for the final step where we used $400 \mu \mathrm{L}$ elution buffer to decrease the concentration of DNA. The yield of DNA was quantified using a NanoDrop 2000 (Thermo Scientific, Waltham, MA, USA).

\subsection{Development of PCR Assays}

PCR primers for the 27 loci were tested using OligoPerfect ${ }^{\mathrm{TM}}$ Designer (ABI), with the following criteria: (i) length of PCR product should be as short as possible and between 90 and 300 bp; (ii) flanking regions should not contain a mononucleotide stretch of more than five bases; (iii) annealing temperature were optimized to fall between 56 and $63{ }^{\circ} \mathrm{C}$; and (iv) difference in temperature between forward and reverse primer should not exceed $2{ }^{\circ} \mathrm{C}$.

Single PCRs were initially performed on 15 individuals for each of the 27 primer pairs, in a $10 \mu \mathrm{L}$ containing 1× PCR Gold buffer (ABI), $200 \mu \mathrm{M}$ dNTP (Eurogentec, Liège, Belgium), $1.5 \mathrm{mM} \mathrm{MgCl} 2$ (ABI), $0.2 \mu \mathrm{M}$ of each primer (ABI), $1 \mathrm{U}$ Amplitaq Gold DNA polymerase (ABI), $1 \times$ BSA (New England Biolabs (NEB), Ipswich, MA, USA) and $1 \mu \mathrm{L}$ template.

DNA amplification was on an ABI 2720 for 10 min at $95{ }^{\circ} \mathrm{C}, 30$ cycles of $30 \mathrm{~s}$ at $94{ }^{\circ} \mathrm{C}, 30 \mathrm{~s}$ at $56{ }^{\circ} \mathrm{C}$, and $1 \mathrm{~min}$ at $72{ }^{\circ} \mathrm{C}$, and ended with final extension for $45 \mathrm{~min}$ at $72{ }^{\circ} \mathrm{C}$.

Multiplex-PCR development involved tests of different combinations of markers and primer concentration (details not shown). For the final analysis, the 21 microsatellites were split into four tetraplex (multiplex I, IV, V and VI), one triplex (multiplex II) and one diplex (multiplex III) in PCR-approach in $10 \mu \mathrm{L}$ reaction volume using the following conditions: $5 \mu \mathrm{L} 2 \times$ multiplex PCR master mix (Qiagen Multiplex kit), $0.05 \mu \mathrm{g} / \mu \mathrm{L}$ BSA (NEB) and adjusted primer set concentrations (Table 1).

PCR conditions for multiplex I-V were $10 \mathrm{~min}$ at $95{ }^{\circ} \mathrm{C}, 25$ cycles of $30 \mathrm{~s}$ at $94{ }^{\circ} \mathrm{C}, 30 \mathrm{~s}$ at $58{ }^{\circ} \mathrm{C}$, $1 \mathrm{~min} 72{ }^{\circ} \mathrm{C}$ and final extension for $45 \mathrm{~min}$ at $72{ }^{\circ} \mathrm{C}$. PCR conditions for multiplex VI were $10 \mathrm{~min}$ at $95^{\circ} \mathrm{C}, 25$ cycles of $30 \mathrm{~s}$ at $94^{\circ} \mathrm{C}, 30 \mathrm{~s}$ at $60^{\circ} \mathrm{C}, 1 \mathrm{~min} 72{ }^{\circ} \mathrm{C}$ and final extension for $45 \mathrm{~min}$ at $72{ }^{\circ} \mathrm{C}$. 
PCR products $(1 \mu \mathrm{L})$ were mixed with Genescan $500 \mathrm{LIZ}(\mathrm{ABI})$ size standard $(0.25 \mu \mathrm{L})$ and Hi-Di formamide $(9.75 \mu \mathrm{L})$ following capillary electrophoresis on an ABI 3130xl Genetic Analyzer (ABI). The POP-7TM (ABI) Polymer was used as separation matrix and the sample injection time were set to 6-8 s/2 kV. PCR fragments were analyzed in GeneMapper 4.1 (ABI).

To check for possible contamination, negative controls were included for every seventh sample in all measurements in this study.

\subsection{Testing for PCR Specificity, Sensitivity and Precision}

All 21 markers were tested for cross-species amplification against DNA samples from two other species, Operophtera brumata $(n=2)$ and Agriopis aurantiaria $(n=2)$. Extraction and PCR were performed as for E. autumnata. Sensitivity of the six multiplex reactions in the 21 STR approach was evaluated using three samples with different amount of template DNA ranging 20-0.1 ng. Measurements of within-run precision were performed in 10 independent amplifications and subsequent runs of a single sample of E. autumnata.

\subsubsection{DNA Sequencing}

The tandem repeat array and the immediate upstream and downstream sequences at each of the 21 loci were analyzed by DNA sequencing. PCR products amplified from E. autumnata were sequenced using the BigDye Terminator v3.1 Cycle Sequencing Kit (ABI) as recommended by the manufacturer. Forward and reverse PCR primers were used as sequencing primers in forward and reverse sequencing reactions, respectively (Table 1). Forward and reverse sequences from each sample were aligned in Sequencher 4.7 (Gene Codes Corporation, Ann Arbor, MI, USA). The allelic sequences from each locus were aligned and the sequence and size variation at each locus was determined by manual inspection. The sequence data from Armalil were used as a guidance of the suggested repeat structure.

\subsubsection{Analysis of Data}

Analysis of Hardy-Weinberg equilibrium (HWE), expected and observed heterozygosities, population structure ( $\mathrm{F}_{\mathrm{IS}}$ ) and test for linkage disequilibrium (LD) were computed with Genetix [29]. Bonferroni corrected significance levels were applied when testing HWE and LD. Micro-Checker ver. 2.2.3 [25] was used to analyze the causes of departures from HWE: real disequilibrium, null alleles or scoring errors.

\section{Conclusions}

We find that these newly developed microsatellites and their multiplex-PCR assays are robust, fast, precise and promising to facilitate further research on fine- and large-scale population genetic studies of E. autumnata.

\section{Supplementary Materials}

Supplementary materials can be found at http://www.mdpi.com/1422-0067/16/09/22541/s1. 


\section{Acknowledgments}

We thank Norwegian Institute for Bioeconomy Research (NIBIO) for financial support and Benedicte Beddari for assistance in the laboratory.

\section{Author Contributions}

All authors contributed to conceive and plan the study. Siv Grethe Aarnes, Ida Fløystad, Julia Schregel, Hans Geir Eiken, and Snorre B. Hagen genotyped the samples, analysed the data and wrote the manuscript with input from all other authors. Jane Uhd Jepsen, Ole Petter Laksforsmo Vindstad, Rolf A. Ims collected the samples.

\section{Conflicts of Interest}

The authors declare no conflict of interest.

\section{References}

1. Kallio, P.; Lehtonen, J. On the plasmatic template system in Micrasterias morphogenesis. Ann. Acad. Sci. Fenn. Biol. 1973, 199, 1-6.

2. Tenow, O.; Bylund, H. Recovery of a Betula pubescens forest in northern Sweden after severe defoliation by Epirrita autumnata. J. Veg. Sci. 2000, 11, 855-862.

3. Karlsen, S.R.; Jepsen, J.U.; Odland, A.; Ims, R.A.; Elvebakk, A. Outbreaks by canopy-feeding geometrid moth cause state-dependent shifts in understorey plant communities. Oecologia 2013, 173, 859-870.

4. Jepsen, J.U.; Biuw, M.; Ims, R.A.; Kapari, L.; Schott, T.; Vindstad, O.P.L.; Hagen, S.B. Ecosystem impacts of a range expanding forest defoliator at the forest-tundra ecotone. Ecosystems 2013, 16, 561-575.

5. Vindstad, O.P.L.; Schultze, S.; Jepsen, J.U.; Biuw, M.; Kapari, L.; Sverdrup-Thygeson, A.; Ims, R.A. Numerical responses of saproxylic beetles to rapid increases in dead wood availability following geometrid moth outbreaks in sub-arctic mountain birch forest. PLOS ONE 2014, doi:10.1371/journal.pone.0099624.

6. Post, E.; Forchhammer, M.C.; Bret-Harte, M.S.; Callaghan, T.V.; Christensen, T.R.; Elberling, B.; Fox, A.D.; Gilg, O.; Hik, D.S.; Hoye, T.T.; et al. Ecological dynamics across the arctic associated with recent climate change. Science 2009, 325, 1355-1358.

7. Hagen, S.B.; Jepsen, J.U.; Schott, T.; Ims, R.A. Spatially mismatched trophic dynamics: Cyclically outbreaking geometrids and their larval parasitoids. Biol. Lett. 2010, 6, 566-569.

8. Hagen, S.B.; Jepsen, J.U.; Yoccoz, N.G.; Ims, R.A. Anisotropic patterned population synchrony in climatic gradients indicates nonlinear climatic forcing. Proc. R. Soc. B Biol. Sci. 2008, 275, 1509-1515.

9. Ims, R.A.; Yoccoz, N.G.; Hagen, S.B. Do sub-Arctic winter moth populations in coastal birch forest exhibit spatially synchronous dynamics? J. Anim. Ecol. 2004, 73, 1129-1136. 
10. Hagen, S.B.; Jepsen, J.U.; Ims, R.A.; Yoccoz, N.G. Shifting altitudinal distribution of outbreak zones of winter moth Operophtera brumata in sub-arctic birch forest: A response to recent climate warming? Ecography 2007, 30, 299-307.

11. Jepsen, J.U.; Kapari, L.; Hagen, S.B.; Schott, T.; Vindstad, O.P.L.; Nilssen, A.C.; Ims, R.A. Rapid northwards expansion of a forest insect pest attributed to spring phenology matching with sub-Arctic birch. Glob. Chang. Biol. 2011, 17, 2071-2083.

12. Jepsen, J.U.; Hagen, S.B.; Ims, R.A.; Yoccoz, N.G. Climate change and outbreaks of the geometrids Operophtera brumata and Epirrita autumnata in subarctic birch forest: Evidence of a recent outbreak range expansion. J. Anim. Ecol. 2008, 77, 257-264.

13. Meglecz, E.; Solignac, M. Microsatellite loci for Parnassius mnemosyne (Lepidoptera). Hereditas 1998, 128, 179-180.

14. Meglecz, E.; Petenian, F.; Danchin, E.; Coeur d'Acier, A.; Rasplus, J.Y.; Faure, E. High similarity between flanking regions of different microsatellites detected within each of two species of Lepidoptera: Parnassius apollo and Euphydryas aurinia. Mol. Ecol. 2004, 13, 1693-1700.

15. Zhang, D.X. Lepidopteran microsatellite DNA: Redundant but promising. Trends Ecol. Evol. 2004, 19, 507-509.

16. Sarhan, A. Isolation and characterization of five microsatellite loci in the Glanville fritillary butterfly (Melitaea cinxia). Mol. Ecol. Notes 2006, 6, 163-164.

17. Hundsdoerfer, A.K.; Sanetra, M.; Corbeil, D.; Stuckas, H. Eleven hawkmoth microsatellite loci of Canary Island Hyles tithymali (Lepidoptera). Conserv. Genet. Resour. 2010, 2, 241-244.

18. Sinama, M.; Dubut, V.; Costedoat, C.; Gilles, A.; Junker, M.; Malausa, T.; Martin, J.-F.; Neve, G.; Pech, N.; Schmitt, T.; et al. Challenges of microsatellite development in Lepidoptera: Euphydryas aurinia (Nymphalidae) as a case study. Eur. J. Entomol. 2011, 108, 261-266.

19. Massardo, D.; Roratto, P.A.; Vargas, H.A.; Kronforst, M.R.; Moreira, G.R.P. Development of a microsatellite library for the passion flower butterfly Dione moneta Hubner (Lepidoptera: Nymphalidae: Heliconiinae). Conserv. Genet. Resour. 2012, 4, 719-724.

20. Weibin, J.; Jianqing, Z.; Ling, Z.; Minghai, C.; Chao, S.; Weidong, Y. Isolation and characterization of microsatellite loci in Polytremis nascens (Lepidoptera: Hesperiidae) and their cross-amplification in related species. Appl. Entomol. Zool. 2014, 49, 177-181.

21. Mira, O.; Martinez, J.G.; Dawson, D.A.; Tinaut, A.; Sanchez-Prieto, C. Twenty new microsatellite loci for population structure and parentage studies of Parnassius apollo nevadensis (Lepidoptera; Papilionidae). J. Insect Conserv. 2014, 18, 771-779.

22. Zima, J., Jr.; Lestina, D.; Jansta, P.; Petru, V.; Tropek, R. Isolation and characterisation of microsatellite markers for Mylothris jacksoni knutsoni (Lepidoptera: Pieridae), an endemic butterfly of the Gulf of Guinea Highlands. Conserv. Genet. Resour. 2014, 6, 763-764.

23. Behura, S.K.; Severson, D.W. Motif mismatches in microsatellites: Insights from genome-wide investigation among 20 insect species. DNA Res. 2015, 22, 29-38.

24. Mende, M.B.; Stuckas, H.; Hundsdoerfer, A.K. Eight new microsatellite loci of the Western Palearctic Hyles euphorbiae complex (Lepidoptera, Sphingidae). Ann. Zool. Fenn. 2011, 48, 142-146.

25. Van Oosterhout, C.; Weetman, D.; Hutchinson, W.F. Estimation and adjustment of microsatellite null alleles in nonequilibrium populations. Mol. Ecol. Notes 2006, 6, 255-256. 
26. Dakin, E.E.; Avise, J.C. Microsatellite null alleles in parentage analysis. Heredity 2004, 93, 504-509.

27. Kim, M.; Kim, H.; Kwon, D.H.; Lee, S. Isolation and characterization of microsatellite loci from Spodoptera exigua (Lepidoptera: Noctuidae). Appl. Entomol. Zool. 2012, 47, 149-152.

28. Sauné, L.; Abella, F.; Kerdelhué, C. Isolation, characterization and PCR multiplexing of 17 microsatellite loci in the pine processionary moth Thaumetopoea pityocampa (Lepidoptera, Notodontidae). Conserv. Genet. Resour. 2015, 7, 755-757.

29. GENETIX, version 4.05: Logiciel sous Windows pour la Génétique des Populations; Laboratoire Génome, Populations, Interactions, CNRS UMR 5171, Université de Montpellier II: Montpellier, France 1996-2004.

(C) 2015 by the authors; licensee MDPI, Basel, Switzerland. This article is an open access article distributed under the terms and conditions of the Creative Commons Attribution license (http://creativecommons.org/licenses/by/4.0/). 